\title{
MATURATION OF THE SOMATOSENSORY EVOKED POTENTIALS IN NORMAL INFANTS AND CHILDREN, WITH SPECIAL REFERENCE TO THE EARLY $N_{1}$ COMPONENT
}

\author{
JOHN E. DESMEDT, E. BRUNKO and J. DEBECKER*
}

Brain Research Unit, University of Brussels, 115, Boulevard de Waterloo, B-1000 Brussels (Belgium)

(Accepted for publication: August 20,1975)

The cerebral somatosensory evoked potentials (SEP) offer exceptional opportunities for testing the nervous system at quite a few levels from peripheral nerve to cortex and these have barely been exploited in neurological diagnosis and perinatal pathology (Halliday 1967; Desmedt 1971). The present paper attempts to provide quantitative SEP reference data which are relevant both to studies of the differential maturation kinetics of the human nervous system and to practical clinical applications of SEP in children at various ages. The emphasis is placed on the features of the early SEP components which signal the precise time of arrival of the afferent impulses at the parietal cortex and which disclose characteristic developmental patterns in the processes of cortical activation.

When recording SEP to contralateral upper limb (finger or nerve) stimulation in normal adult man, a small negative component called " 1 ", $\mathrm{N}_{1}$ or $\mathrm{N}_{20}$ (since its peak latency is about $20 \mathrm{msec}$ ) has been noted (Allison 1962; Debecker and Desmedt 1964; Giblin 1964) and it is now considered to represent the first cortical event of SEP (cf. Goff et al. 1969; Desmedt 1971; Cracco 1972; Small et al. 1975). The $\mathrm{N}_{1}$ component has perhaps not been adequately considered in several studies dealing with late SEP components and it has sometimes even been missed as a result

* Deceased November 30, 1974. of the use of inadequate recording systems with a bandpass failing to extend to 1 or $3 \mathrm{kc}$ (Desmedt et al. 1974). The potential significance of the early negativity was dramatically emphasized when large and prolonged $\mathrm{N}_{1}$ was recorded in normal human neonates (Desmedt et al. 1967; Desmedt and Manil 1970) and in premature babies (Hrbek et al. 1973; Desmedt and Sacré, in preparation). The diverse features of $\mathrm{N}_{1}$ in newborn and adult respectively could indeed have suggested a difference in their nature. However, the present analysis of SEP in infants and children discloses a remarkable continuity in the changes whereby the newborn $\mathrm{N}_{1}$ is transformed over a period of about 8 years into the adult pattern.

Much care was exercised to optimize the recording methods and to exclude interference. In each subject the data were replicated at least 3 times with different scalp recording sites in order to delineate the $\mathrm{N}_{1}$ features consistently and to define onset latencies with $0.2 \mathrm{msec}$ accuracy. Peripheral stimuli were delivered to the fingers (Dawson 1956), not to the mixed nerves, in order to secure more reliably defined afferent signals. The children and adults were studied awake with eyes open. The neonate data were all collected in Rapid Eye Movement (REM) sleep episodes, in which SEPs had been shown to resemble rather closely those in the waking state (Desmedt and Manil 1970). 
Methods

Subjects. The study involved 29 normal full term babies delivered after an uncomplicated pregnancy and 35 healthy children between 1 month and 9 years of age, with no evidence of neurological disease and no anomaly of growth or nutrition*. The neonates had an Apgar (1953) index of at least 8 at birth and of 10 after $5 \mathrm{~min}$. They were studied between 2 and 6 days after birth. The 2 sexes were about equally represented in the groups. All subjects had normal EEGs. Informed consent was obtained from parents or guardians in each case. Additional observations were made on 16 normal adult volunteers between 21 and 37 years of age who were medical students or staff members.

Stimulation and recording. Square electrical pulses of 0.5 or $0.2 \mathrm{msec}$ duration were delivered to one or more fingers of the contralateral hand through silver strips (with electrode jelly) placed around the proximal and distal finger segments. The cathode was proximal and a separate stimulator was used for each finger, all stimulators being triggered by the same pulse of the electronic program. The current actually flowing through each pair of electrodes was monitored on an oscilloscope with a Hewlett Packard model $1111_{\mathrm{A}}$ probe. A silver plate or a steel needle in the proximal arm connected the subject to earth. For scalp recording, sterile stainless steel needles 0.2 or $0.3 \mathrm{~mm}$ diameter were inserted subcutaneously over the parietal region, 50 to $75 \mathrm{~mm}$ from the midline, depending on the skull size and age of the subject. Negativity of the active electrodes produced an upward deflection. The reference electrode was a steel needle in the mid upper forehead. These fine needles insured a constant low impedance and a

* We wish to thank Prof. P. Hubinont (Department of Obstetrics) and Dr. J. Namèche (Department of Paediatrics) for their kind cooperation. precise focal recording (Desmedt and Manil 1970). They were well tolerated during long sessions while other methods involving silver discs or harness were found unpractical. The brain potentials were led through high input impedance differential amplifiers into a Nicolet model 1062 or 1074 digital computer.

The data were also stored in most sessions on an Ampex 14-channel FR-1300 magnetic recorder operated at 15 in./sec. This was necessary in the newborn studies to allow subsequent off-line pooling of the SEP data recorded during different episodes of REM sleep of the same session. The stages of sleep were carefully identified by polygraph recording of the EMG of the submentalis muscle, the vertical and horizontal electro-oculograms and the EEG. No polygraph recording was used in the children and adults who were studied in the waking state with the eyes open, but the EEG was always monitored on oscilloscopes. A special program was used in investigating SEPs to near-threshold stimuli: in order to minimize the influence of changes of the subject's state during runs, 4 different stimulators were connected to one finger and they were triggered in turn during each run and the electronic program coded each stimulus on a technical channel of the magnetic recorder. The SEPs to each of the 4 stimulus intensities were subsequently averaged separately when reading the tape into the computer (Fig. 1 to 3 ).

Appropriate definition of SEPs was achieved by averaging many samples, 512 to 2048 in most runs, while excluding the samples with excess noise, amplifier overload or gross movement artifacts. This could be achieved on-line by using half the 1074 averager's memory as an input buffer from which any sample not exceeding chosen voltage levels was automatically transferred to the other memory half for averaging. Another method involved the editing of the tape-recorded data for off-line averaging (cf. Debecker and Carmeliet 1974). The 


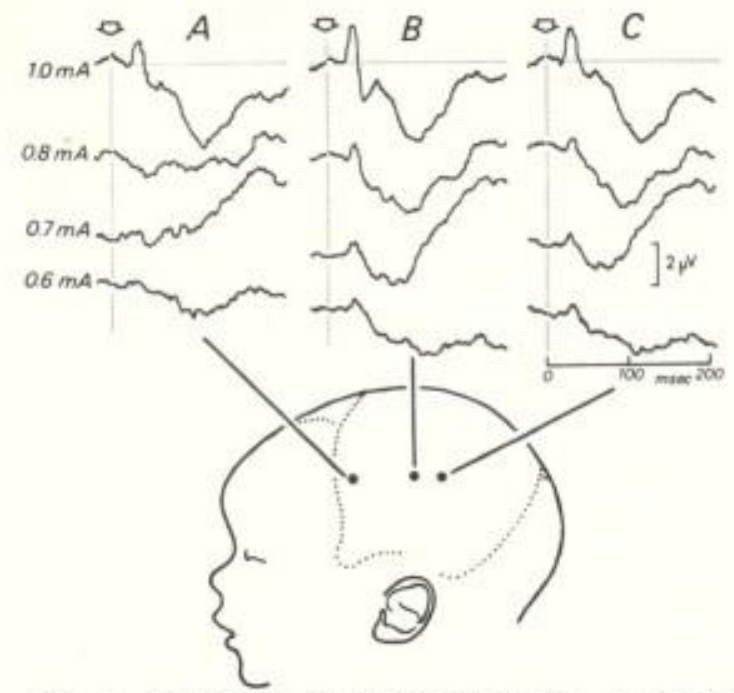

Fig. 1. Restricted scalp focus of $\mathrm{N}_{1}$ in neonates for near-threshold stimuli. Normal female newborn, 3 days, $3.08 \mathrm{~kg}$. Pooled runs $(\mathrm{N}=128)$ carried out in REM sleep with 4 stimulus intensities delivered in turn to finger II of the contralateral hand. Random intervals (minimum $2 \mathrm{sec}$ ) between successive stimuli. Simultaneous records from 3 active electrodes (referred to upper forehead) located $5 \mathrm{~mm}(A), 25 \mathrm{~mm}(B)$ and $35 \mathrm{~mm}(C)$ respectively behind the fronto-parietal suture.

overall time constant was $0.5 \mathrm{sec}$. The system bandpass extended to $3 \mathrm{kc}$ and the averager operated at 50 or $100 \mu \mathrm{sec}$ bin width to avoid any distortion of the fast transients in the $\mathrm{N}_{1}$ component (Desmedt et al. 1974). The successive finger stimuli were triggered in most cases at random intervals generated by Beta emission (Carmeliet et al. 1971) with the minimum intervals of the series being set at either $2 \mathrm{sec}$ (for neonates) or $1 \mathrm{sec}$ (for children and adults). Thus large numbers of samples could be secured during the session and the conditions represented a compromise designed for optimal analysis of the early SEP components. Other conditions would obviously be required when studying late components (Desmedt and Manil 1970; Desmedt and Debecker 1972).

Procedure. The 29 newborns were brought from the nearby maternity hospital to the Unit for $2-3 \mathrm{~h}$ between feeds. They were studied in a crib placed in a sound-proof air-conditioned $\left(24^{\circ} \mathrm{C}, 50 \%\right.$ humidity) shielded room (Hougardy and Desmedt 1967). After the electrodes had been placed the babies went undisturbed through their sleep cycles. The intensity of finger stimulation was adjusted to avoid interference with the natural sleep states. For example, synchronous stimulation of, say, 3 fingers by separate stimulators, each delivering $3 \mathrm{~mA}$, was better tolerated than the delivery of $9 \mathrm{~mA}$ to a single finger and yet elicited SEPs of about similar size (cf. Debecker and Desmedt 1964).

The children were studied in the waking state with their eyes open, for a period of about $4 \mathrm{~h}$. About half of them received a suppository of $100 \mathrm{mg}$ Nembutal which helped reduce apprehension without however eliciting sleep. Obtaining the necessary state of relaxation with no phasic movements of body, head and eyes in these children was a quite challenging task. A rather intense human relation involving explanations, jokes, story telling and reading comic books was maintained throughout the session by both the experimenter and an expert nurse (Madame Stage). The children also received small toys as reward for periods of quiet relaxation. In spite of the difficulties presented by EP studies in awake children, the complete program of about 5 runs of SEP averaging and of sensory nerve potential recording was successfully carried out in the 35 subjects considered. The 16 adult subjects were seated in an easy chair with the neck and jaw muscles relaxed and with open eyes, looking at a fixed point to minimize eye movements. In all subjects, the skin temperature of the upper limb was maintained between 34 and $36^{\circ} \mathrm{C}$, as measured by a thermistor plate, which ensured a fairly normal temperature of deep tissues. This is important to exclude slowing of conduction velocity in peripheral nerve fibres which would result in spurious overestimates of SEP latencies. 


\section{Results}

SEPs in newborns. Several features of the early SEP components were closely investigated in relation to the proposed study. As is well known, newborns are sleeping most of the time between feeds; the brief periods of waking generally did not permit adequate SEP runs to be carried out. As a rule the data were therefore collected in typical REM sleep runs in which the eyes were closed and bursts of eye movements could be seen as fast movements of the eyelids; muscle twitches in the face and limbs were observed and the submentalis electromyogram (EMG) was flat with occasional bursts; the respiration was slightly irregular and the EEG showed low voltage fast activity (cf. Roffwarg et al. 1966; Desmedt and Manil 1970; Anders et al. 1971).

The scalp electrodes are more remote from the parietal cortical generators in the adult than in the newborn (thickness of bone, etc.) and, in the latter, the positions of the active electrodes proved rather critical, especially when studying the early SEP components which are more focal. With monopolar electrodes $10 \mathrm{~mm}$ apart in a horizontal row, about $55 \mathrm{~mm}$ lateral to the midline, fairly comparable SEPs could be recorded over a distance of, say, $30 \mathrm{~mm}$ for suprathreshold stimuli to one finger (Fig. 1). However, when the stimulus intensity dropped below $1 \mathrm{~mA}$ in this example, $\mathrm{N}_{1}$ disappeared from the more anterior leads and became confined to a focal scalp region $20 \mathrm{~mm}$ behind the bi-auricular frontal plane of the head. Fig. 2 presents SEPs recorded from the optimal scalp focus for different intensities (see Methods). In $A$, the finger stimulus of $0.6 \mathrm{~mA}$ was not followed by any definite potential configuration and the trace did not differ significantly from a control "Add-Sub" average (cf. Schimmel 1967). In $B, 0.8 \mathrm{~mA}$ elicited a prominent $\mathrm{N}_{1}$ of $1.4 \mu \mathrm{V}$ with the unusually long latency of $38.5 \mathrm{msec}$. This $\mathrm{N}_{1}$

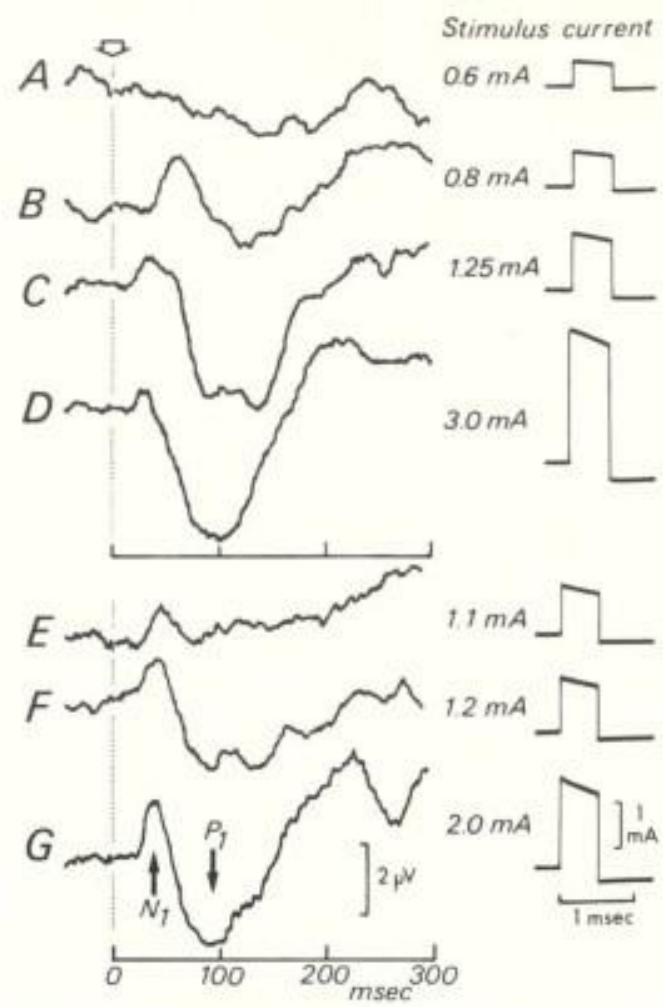

Fig. 2, Early near-threshold components in the normal newborn. Records from the $\mathrm{N}_{1}$ scalp focus, referred to the upper forehead. Pooled runs $(\mathrm{N}=$ 128) in REM sleep with several stimulus intensities delivered in turn to finger II of the contralateral hand. Oscilloscope records of the stimulus current appear on the right. Random intervals (minimum $2 \mathrm{sec}$ ) between successive stimuli. $A-D$, male newborn, 3 days, $3.3 \mathrm{~kg} . E-G$, male newborn, 2 days, $3.27 \mathrm{~kg}$.

was followed by a positive $\mathrm{P}_{1}$ component of $1.2 \mu \mathrm{V}$. For $1.25 \mathrm{~mA}$ in $C, \mathrm{~N}_{1}$ was smaller $(0.84 \mu \mathrm{V})$ and had a shorter latency of 20.5 msec while $P_{1}$ increased to $3.5 \mu \mathrm{V}$. For $3 \mathrm{~mA}$ in $D, \mathrm{P}_{1}$ further increased. The data from another neonate showed at the threshold intensity $1.1 \mathrm{~mA}$ (Fig. 2, E) an interesting prominence of $\mathrm{N}_{1}$ which did not appear to be followed by any significant positive component. In this baby the $\mathrm{N}_{1}$ voltage was not reduced when the intensity increased but $\mathrm{N}_{1}$ actually augmented along with the $\mathrm{P}_{1}$ voltage (Fig. $2, F, G$ ). 
A systematic study confirmed the marked changes in early SEP components for nearthreshold intensities. The voltage of $\mathrm{N}_{1}$ was generally below $2 \mu \mathrm{V}$ for stimuli smaller than $2 \mathrm{~mA}$. It did not increase markedly for intensities between 3 and $12 \mathrm{~mA}$ (Fig. $3, A)$. In 4 babies, presumably tested at the appropriate near-threshold intensities, $\mathrm{N}_{1}$ was present (mean voltage $0.5 \mu \mathrm{V}$ ) while a positive component could not be detected (Fig. 4, A). When considering $\mathrm{N}_{1}$ voltage as a function, not of the stimulus intensity, but of the $P_{1}$ voltage in 39 runs with single finger stimulation (Fig. $4, A$ ), $\mathrm{N}_{1}$ appeared to increase along with $\mathrm{P}_{1}$; the data were rather scattered but the relation was highly significant $\left(r^{2}=0.443\right)$. Data from the same runs suggested also that the duration of $\mathrm{N}_{1}$ tended to be long when $\mathrm{P}_{1}$ was small and that it decreased when $P_{1}$ became larger
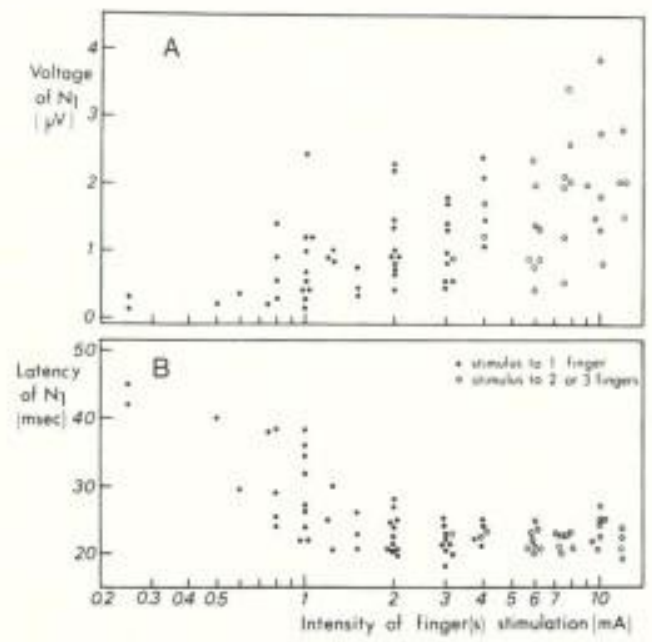

Fig. 3. The effect of stimulus intensity in $\mathrm{mA}$ (abscissa, log scale) on the voltage in $\mu \mathrm{V}(A)$ and on the onset latency in msec $(B)$ of the $\mathrm{N}_{1}$ component in 29 normal newborns. All runs carried out during REM sleep. Dots, 48 runs with stimulation of a single finger of the contralateral hand at various intensities in 11 newborns. Circles, 29 runs with synchronous stimulation of 2 or 3 fingers of the contralateral hand. For the latter data, the abscissae indicate the sum in $\mathrm{mA}$ of the currents delivered to the 2 or 3 fingers.

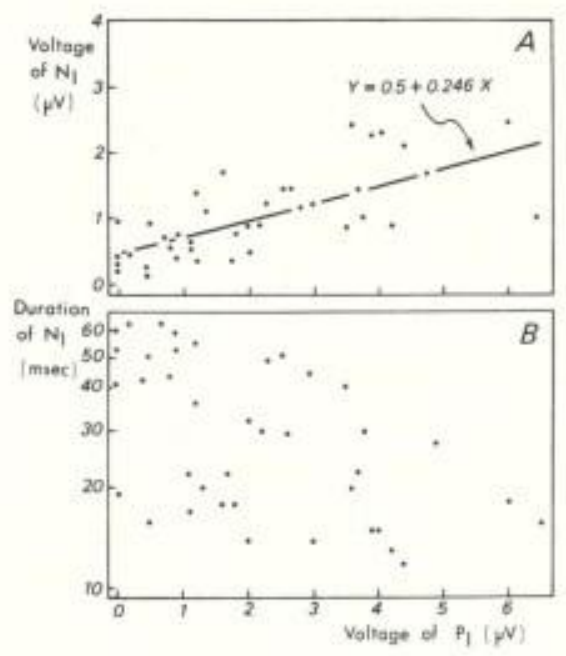

Fig. 4. Scatter diagrams relating the peak voltage of the $\mathrm{P}_{1}$ component (abscissa) to the peak voltage $(A)$ or to the duration $(B)$ of the corresponding $\mathrm{N}_{1}$ component. Pooled results of 39 runs in 11 normal newborns studied in REM sleep. Stimulation of a single finger of the contralateral hand at various intensities.

(Fig. 4, B). The correlation was moderately significant $\left(r^{2}=0.277\right)$. A more consistent relation was found between the onset latency of $\mathrm{N}_{1}$ and the stimulus intensity (Fig. 3, B). The $\mathrm{N}_{1}$ latency could exceed $40 \mathrm{msec}$ at the lowest intensities. It decreased with higher intensities and reached its minimum value $(22.5 \pm 1.9 \mathrm{msec}$, S.D. $)$ for stimuli exceeding $3 \mathrm{~mA}$.

These observations suggest that, when comparing subjects of different ages, it would not be safe to compare early SEP components unless the finger stimuli were sufficiently strong to exclude the observed juxtathreshold increases in $\mathrm{N}_{1}$ latency and duration. As a rule the SEPs considered in this paper were elicited by stimuli exceeding $3 \mathrm{~mA}$, delivered either to one finger or (more frequently) simultaneously to 2 fingers. No attempt was made to deal with possible variations in the interaction of $\mathrm{N}_{1}$ and $\mathrm{P}_{1}$ at different stimulus intensities since rather standard conditions appeared to prevail 
for stimuli exceeding about 3 times the threshold (Fig. 3 and the right third of Fig. 4). The time available in each session

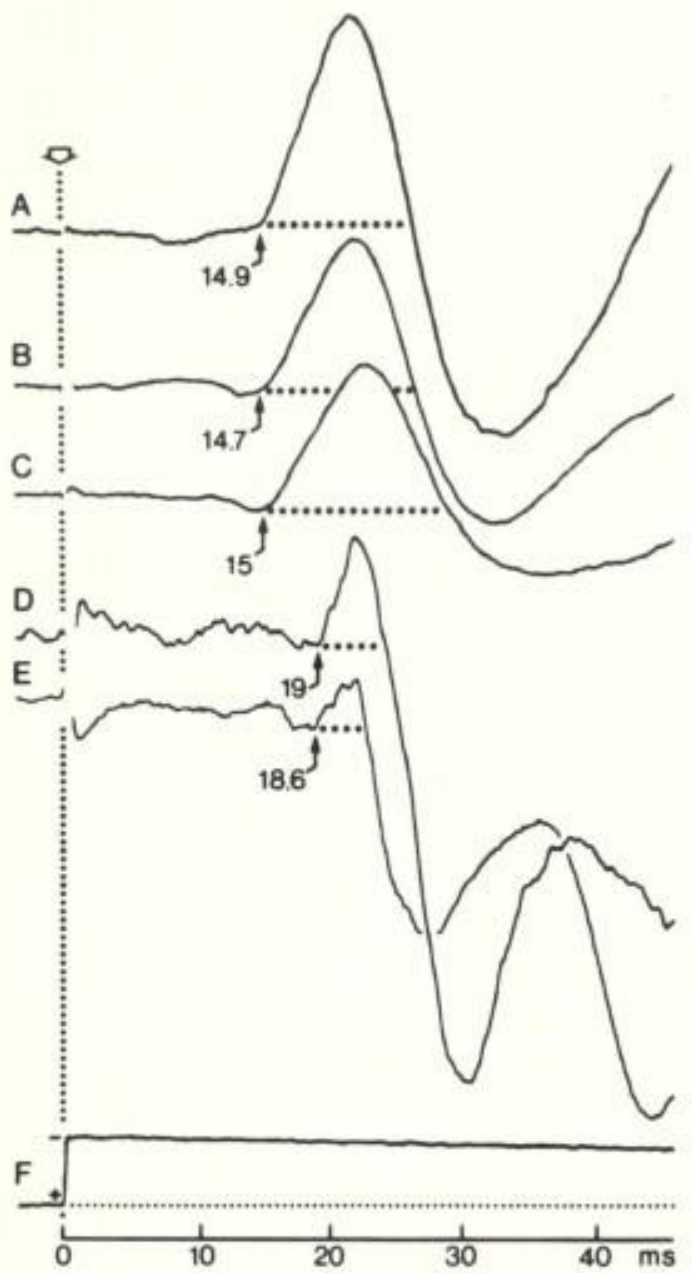

Fig. 5. SEPs to stimulation of 2 fingers of the contralateral hand with stimuli of $10 \mathrm{~mA}$. $A$ to $C$, female child of 8 months and 21 days after birth, $7.1 \mathrm{~kg}$ and $67 \mathrm{~cm}$ body length. $A$ and $C$, different runs but same active electrode located $60 \mathrm{~mm}$ lateral to the midline, $B$, electrode $50 \mathrm{~mm}$ lateral to the midline. The 2 electrodes were $20 \mathrm{~mm}$ behind the bi-auricular frontal plane. $D$, normal male adult, 27 years, $E$, another male adult, 36 years. Random intervals (minimum $1 \mathrm{sec}$ ) between stimuli. Bin width $50 \mu \mathrm{sec}$. Averages of 1024 samples. Subjects awake with eyes open. $F$, calibrating voltage step function equivalent to $0.5 \mu \mathrm{V}$ for $A-C$ and to 1.25 $\mu \mathrm{V}$ for $D$ and $E$. was better used to make a sufficient number of runs to estimate reliably the features of the components.

SEPs in children and adults. The optimal scalp recording sites on the parietal area varied in the different subjects as a function of skull size. The largest and most consistent average records were obtained from electrodes located $10-35 \mathrm{~mm}$ behind the bi-auricular frontal plane. Fig. 5, $A-C$ show typical SEPs in a child of nearly 9 months. The onset latency of the prominent $\mathrm{N}_{1}$ component was found between 14.7 and $15.0 \mathrm{msec}$ in these 3 and in 3 other records (mean $14.9 \mathrm{msec}$ ). The $\mathrm{N}_{1}$ duration ranged from 11.1 to $13.3 \mathrm{msec}$, with a mean of $12.0 \mathrm{msec}$. The mean $\mathrm{N}_{1}$ voltage was $1.5 \mu \mathrm{V}$. The 2 fairly representative adult SEPs in $D$ and $E$ show a consistent, but less prominent, early negative component. The $\mathrm{N}_{1}$ duration is much shorter and the subsequent positive component $\mathrm{P}_{1}$ is larger. The mean latency to onset of $\mathrm{N}_{1}$ was $18.8 \pm 1.3$ (S.D.) $\mathrm{msec}$ in the 16 adults and definitely exceeded the values for the children up to 9 years (see later).

Fig. 6 shows that SEPs retain quite immature features during the second year after birth. In the child of 14 months and 1 week the $N_{1}$ onset latency ranged between 14.3 and $14.7 \mathrm{msec}$, with a mean of $14.5 \mathrm{msec}$ (Fig. 6, $A-C$ ). The $\mathrm{N}_{1}$ duration was from 10.2 to $12.6 \mathrm{msec}$ with a mean of $11.4 \mathrm{msec}$. The $\mathrm{N}_{1}$ voltage was $2.0 \mu \mathrm{V}$. Another child of 20 months and 11 days presented $\mathrm{N}_{1}$ latencies between 15.7 and $16.1 \mathrm{msec}$ with a mean of $15.8 \mathrm{msec}$ (Fig. $6, D-F)$. The mean duration of $\mathrm{N}_{1}$ was $8.3 \mathrm{msec}$, which is less than in younger children but still definitely larger than in adults. Fig. 6, $G$ draws attention to the important $\mathrm{N}_{1}$ distortion which can result from placing the active electrode too far anteriorly. The peaks of $\mathrm{N}_{1}$ and of $\mathrm{P}_{1}$ in fact coincide with those in the above records of the same session $(D-F)$. However, the onset latency of the negative component in $G$ is now measured as $17.5 \mathrm{msec}$ 


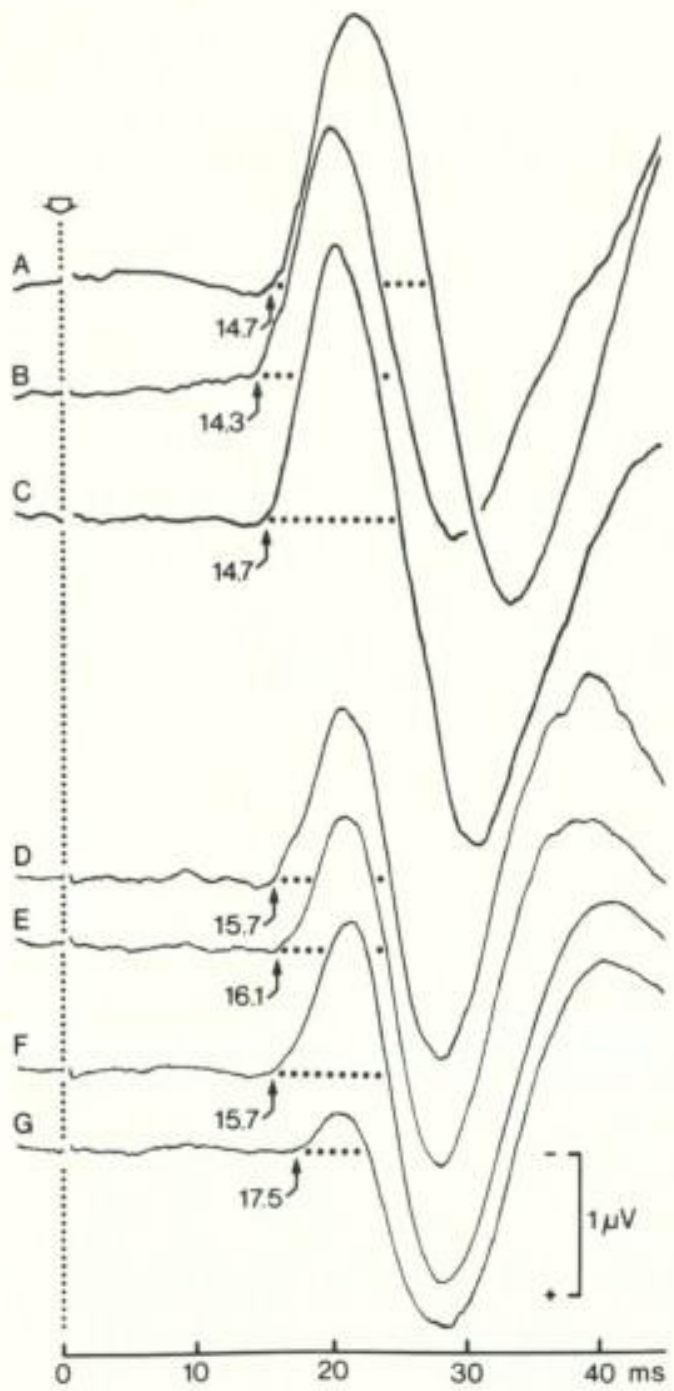

Fig. 6. SEPs to stimulation of 2 fingers of the contralateral hand with stimuli of $10 \mathrm{~mA}$. $A$ to $C$, male child of 14 months and 1 week, $11.6 \mathrm{~kg}$ and $79 \mathrm{~cm}$ body length. Active electrode $70 \mathrm{~mm}$ lateral to midline in $A, 60 \mathrm{~mm}$ lateral in $B$ and $C$. These electrodes were between 10 and $25 \mathrm{~mm}$ behind the biauricular frontal plane, $D$ to $G$, male child of 1 year 8 months and 11 days, $12.2 \mathrm{~kg}$ and $87 \mathrm{~cm}$ body length. Four different active electrodes in separate runs. The electrodes in $D, E$ and $F$ were $70 \mathrm{~mm}$ lateral to the midline and from 20 to $40 \mathrm{~mm}$ behind the bi-auricular frontal plane. The electrode in $G$ was sub-optimally placed $60 \mathrm{~mm}$ from midline and on the bi-auricular frontal plane. Bin width $50 \mu \mathrm{sec}$. Averages of 1024 or 2048 samples. Subjects awake with eyes cpen. and its duration as $5.2 \mathrm{msec}$. Thus, when recording outside the parietal hand focus, one can easily be misled into thinking that $\mathrm{N}_{1}$ has acquired adult characteristics in

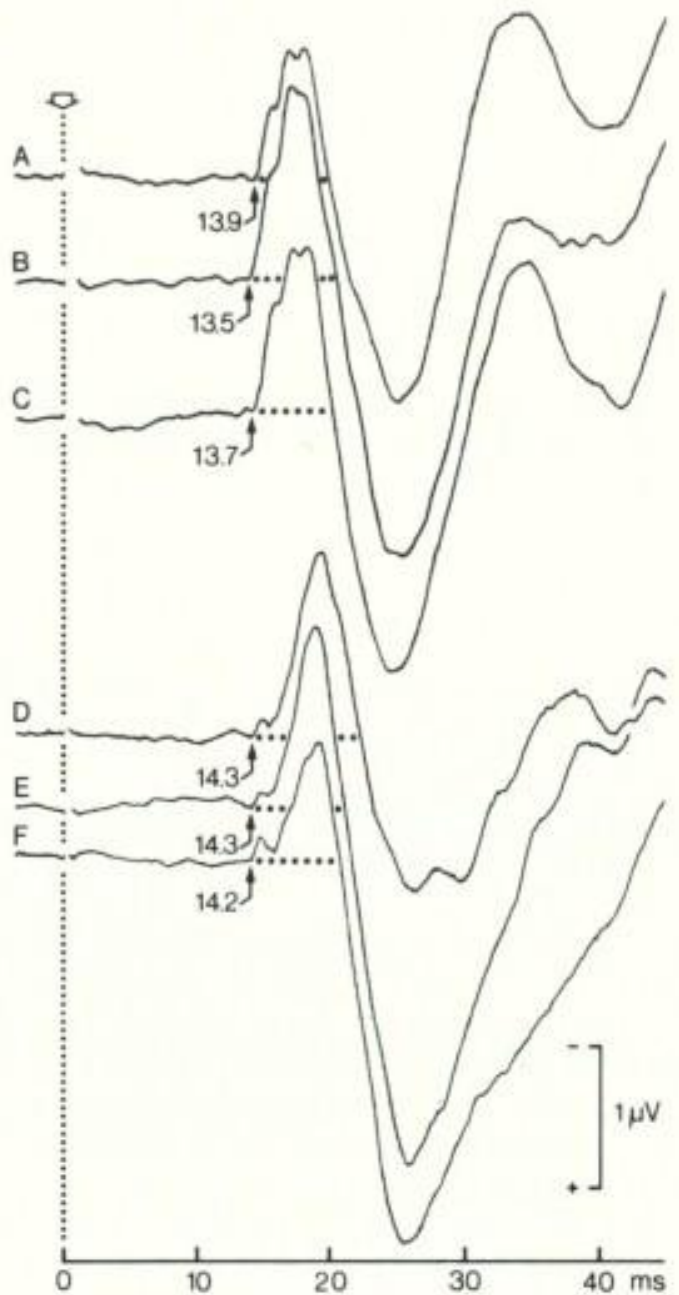

Fig. 7. SEPs to stimulation of 2 fingers of the contralateral hand with stimuli of $10 \mathrm{~mA} . A$ to $C$, female child of 4 years 11 months, $16.0 \mathrm{~kg}$ and $102 \mathrm{~cm}$ body length. Three different active electrodes in separate runs. The electrodes were $70 \mathrm{~mm}(A$ and $B)$ and $60 \mathrm{~mm}(C)$ lateral to the midline and from 15 to $25 \mathrm{~mm}$ behind the bi-auricular frontal plane. $D$ to $F$, female child of 6 years 4 months, 23.0 $\mathrm{kg}$ and $121 \mathrm{~cm}$ body length. Active electrodes 65 $\mathrm{mm}$ lateral to the midline and from 15 to $35 \mathrm{~mm}$ behind the bi-auricular frontal plane. Bin width $50 \mu \mathrm{sec}$. Averages of 1024 samples. Subjects awake with eyes open. 
the second year or indeed before that time. We feel that such inadequate recording could explain some of the claims by Laget et al. $(1973 \mathrm{a}, \mathrm{b})$ that SEP wave forms acquire the adult pattern within as little as 16 weeks after birth. It is also obvious that SEPs, such as shown in Fig. $6, G$, have a delayed onset and that they would provide spurious estimates of the earliest time of arrival of afferent signals at the parietal cortex.

Fig. 7 shows SEPs of children in their fourth or sixth years. The onset latencies of $\mathrm{N}_{1}$ are still quite short, with a mean of 13.6 msec in $A-C$ and $14.3 \mathrm{msec}$ in $D-F$. An interesting feature frequently observed at these ages is that the main $N_{1}$ deflection can be preceded by a sort of negative "step" which can very well be mistaken for background noise residue in the single average record, but appears quite consistent when several average records are compared (Fig. 7, $D-F$ ). We think these early $\mathrm{N}_{1}$ steps could result from the more rapid maturation (and hence higher conduction velocity) of a few lemniscal or thalamo-cortical axons which start activating the parietal cortex about $1.5 \mathrm{msec}$ ahead of the others. Such features have not been described in adult SEPs where the afferent volley is presumably more synchronized. In pathological adult cases, such as vascular lesions of the lemniscus in the brainstem, another type of afferent desynchronization has been described (Noèl and Desmedt 1975) in which the main $\mathrm{N}_{1}$ deflection is followed by one or more surface-negative elevations, possibly associated with retarded (not earlier ones as assumed in children) afferent signals. The mean $\mathrm{N}_{1}$ durations of $5.8 \mathrm{msec}$ and $7.0 \mathrm{msec}$ respectively in the children of Fig. 7 still exceed the adult range. These durations of course include the early $\mathrm{N}_{1}$ step, which is thought to indicate the true earliest onset of the cortical negative component.

Selected SEPs at different ages are assembled in Fig. 8 to illustrate some of the

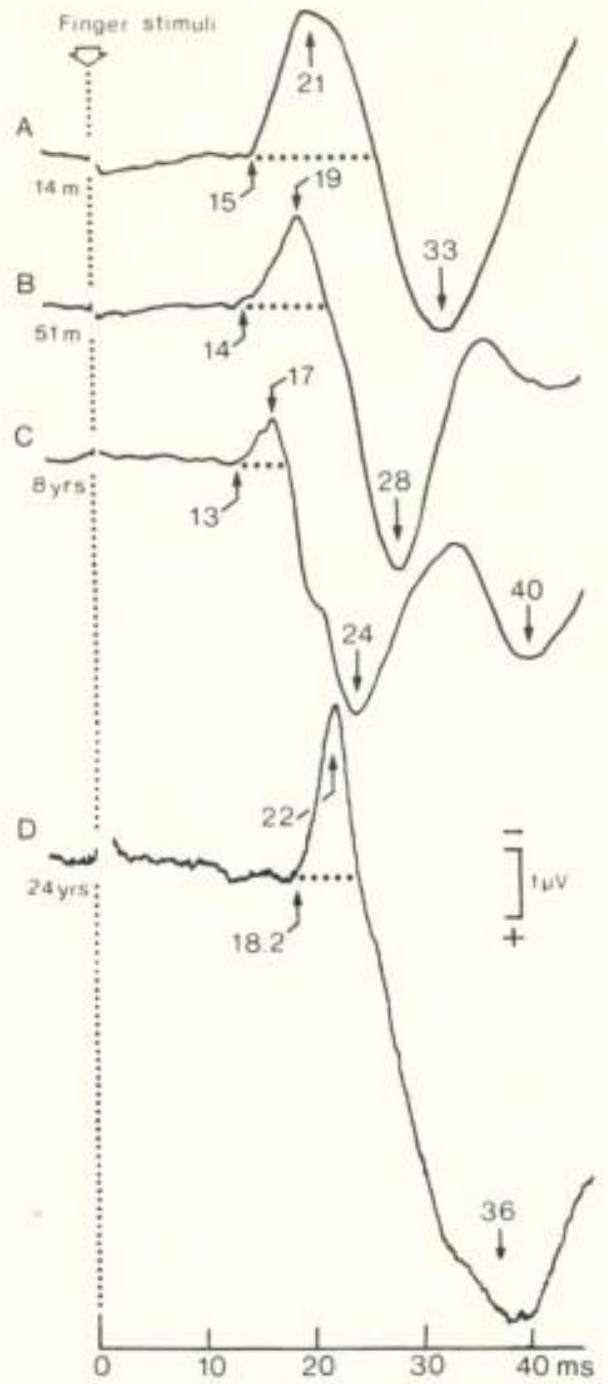

Fig. 8. Comparison of SEPs to stimulation of 2 fingers of the contralateral hand with 5 or $10 \mathrm{~mA}$. Optimal active electrode placement on the parietal focus. Forehead reference. Bin width $50 \mu \mathrm{sec}$. Averages of 512 or 1024 samples. $A$, male child of 14 months 1 week, $11.6 \mathrm{~kg}$ and $79 \mathrm{~cm}$ body length. $B$, male child of 4 years 3 months and 7 days (or 51 months), $16.6 \mathrm{~kg}$ and $103 \mathrm{~cm}$ body length. $C$, female child of 8 years and 6 months, $22.0 \mathrm{~kg}$ and $118 \mathrm{~cm}$ body length. $D$, male adult of 24 years, $64 \mathrm{~kg}$ and $176 \mathrm{~cm}$ body length. All subjects awake with eyes open. Same calibration for all traces.

progressive changes after birth. Prominent features are the reduction in the duration of $\mathrm{N}_{1}$ and the relative increase in the size 
TABLE I

\begin{tabular}{llll}
\hline & $\begin{array}{l}3-24 \\
\text { months }\end{array}$ & Adults & $t$ test \\
\hline Voltage of $\mathrm{N}_{1}$ & $1.8 \pm 1.3$ & $1.6 \pm 1.1$ & n.s. \\
Voltage of $\mathrm{P}_{1}$ & $2.0 \pm 1.5$ & $5.5 \pm 3.5$ & $P<0.02$ \\
$\mathrm{~N}_{1}: \mathrm{P}_{1}$ & $0.93 \pm 0.22$ & $0.31 \pm 0.17$ & $P<0.001$ \\
\hline
\end{tabular}

of the early positive component following $\mathrm{N}_{1}$. The adult SEP in $D$ presents a rather large $N_{1}$ of $2.6 \mu \mathrm{V}$. In fact the $N_{1}$ voltage varies more among subjects at any age than the $\mathrm{N}_{1}$ duration and there is no significant difference in mean $\mathrm{N}_{1}$ voltage between infants and adults (Table I). The positive component in $D$ has a single peak at 36 msec rather than the more usual two peaks called $\mathrm{P}_{28}$ and $\mathrm{P}_{45}$ respectively (cf. Allison 1962; Giblin 1964; Debecker and Desmedt 1964; Goff et al. 1969). Quantitative data on the various features of the early SEP components are presented in Fig. 9 to 11 . The data for newborns in REM sleep and for adults are represented by their mean values. The $\mathrm{N}_{1}$ duration discloses a consistent progressive decrease which has apparently not yet reached the adult range by the eighth year after birth (Fig. 9, A). Notice that the S.D. for $\mathrm{N}_{1}$ duration in adults is quite small. The data fit very well a negative power function which is drawn through the points.

The mean $\mathrm{N}_{1}$ onset latency is $22.5 \pm 1.9$ $\mathrm{msec}$ in the newborns and $18.8 \pm 1.3 \mathrm{msec}$ in the adults and the difference is highly significant $(P<0.001)$. The $\mathrm{N}_{1}$ latency ranges between 12.5 and $16.0 \mathrm{msec}$ in the children from about 6 months to 9 years (Fig. $9, B)$. Since a major factor determining the SEP latency is the conduction time from fingers to cortex (cf. Desmedt 1971; Desmedt et al. 1973), one must take into account the increasing length of the pathway in the growing children whose body length is plotted in Fig. 9, C. A remarkable relation is then found by plotting the $\mathrm{N}_{1}$ onset latency

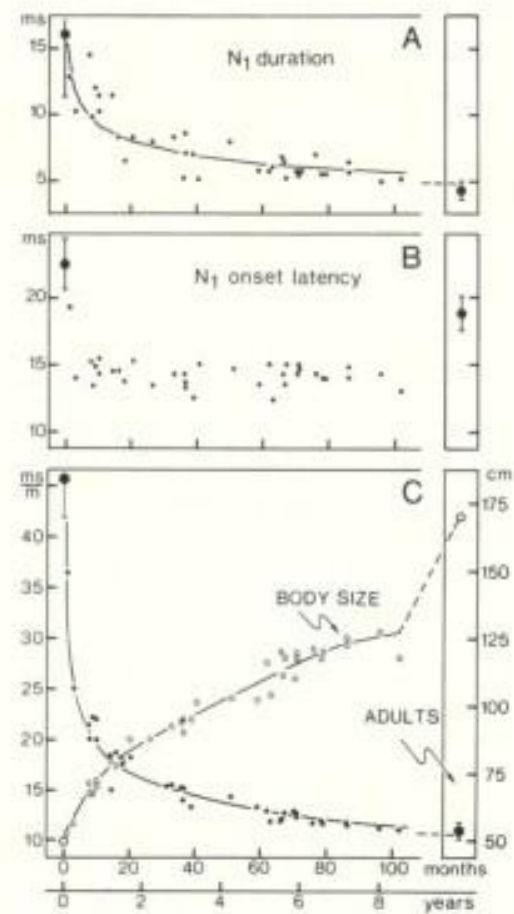

Fig. 9. Pooled data on $\mathrm{N}_{1}$ duration and $\mathrm{N}_{1}$ onset latency. Abscissa, age in months and in years (bottom scale). The data on the 39 newborns studied in REM sleep appear as a single point (mean and S.D.) on the abscissa zero. Each of the 35 children contributes to each graph one point which is the mean of estimates on at least 3 SEPs. The data for the 16 adults appear in the box on the right (mean and S.D.). $A, \mathrm{~N}_{1}$ duration in msec with curve drawn according to the calculated power function: $y=$ $14.51 \mathrm{x}^{-0.204}\left(\mathrm{~N}=37, \mathrm{r}^{2}=0.751\right) . B, \mathrm{~N}_{1}$ onset latency in msec. $C$, circles, body length in $\mathrm{cm}$ with the corresponding scale on the right of the graph. $C$, dots, $\mathrm{N}_{1}$ onset latency divided by body length in $\mathrm{msec} / \mathrm{m}$ with curve drawn according to the calculated power function: $y=32.44 x^{-0.221}(N=37$; $\left.r^{2}=0.962\right)$

divided by body length. The data can be fitted by a negative power function with an $\mathrm{r}^{2}$ as high as 0.965 (Fig. 9, $C$ ). In spite of the large growth at puberty, the function considered reaches the adult range at 7 or 8 years of age.

The latencies to the peak of $\mathrm{N}_{1}$ in the children are also below those of either the newborns or the adults (Fig. 10, A). When 


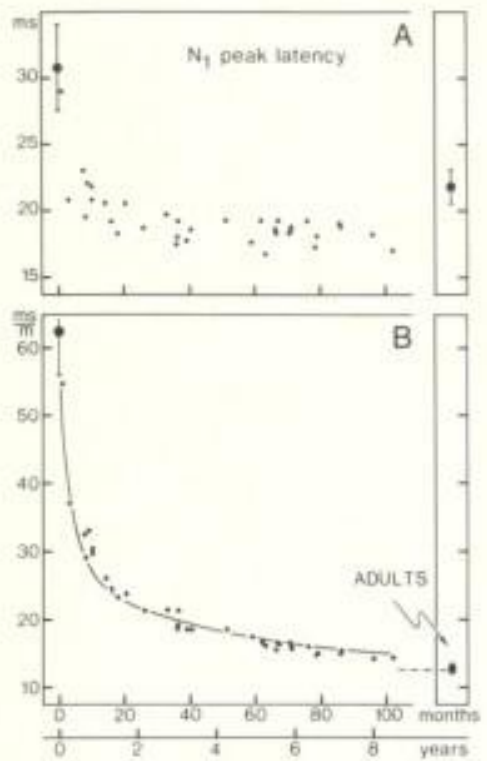

Fig. 10. Pooled data on $\mathrm{N}_{1}$ peak latency; presented as in Fig. 9. Abscissae, age in months or years (bottom scale). The data for the adults appear in the box on the right. $A, \mathrm{~N}_{1}$ peak latency in msec. $B, \mathrm{~N}_{1}$ peak latency divided by the body length in $\mathrm{msec} / \mathrm{m}$, with a curve drawn according to the calculated power function: $y=47.74 x^{-0.249}\left(N=37, r^{2}=\right.$ 0.951 ),

each latency is divided by the body size of the subject, the data become very consistent and they are closely fitted by a negative power function (Fig. 10, B). At 8 years the plot does not appear to reach the adult range, which is quite small. When plotting the latencies to the peak of $P_{1}$ we took into account the first positive peak, which is $\mathrm{P}_{27}$ in the adult. In the newborns the later part of the positive component was not taken into consideration when there was a double positive peak. The points are more scattered (Fig. 11, A) and this seems to result from the larger variation in the wave forms of the positive component. The plot of the $\mathrm{P}_{1}$ peak latency divided by the body length was nevertheless very consistent with an $\mathrm{r}^{2}$ of 0.909 (Fig. 11, B).

The voltage of $\mathrm{N}_{1}$ and $\mathrm{P}_{1}$ varied over a rather large range in the different subjects.

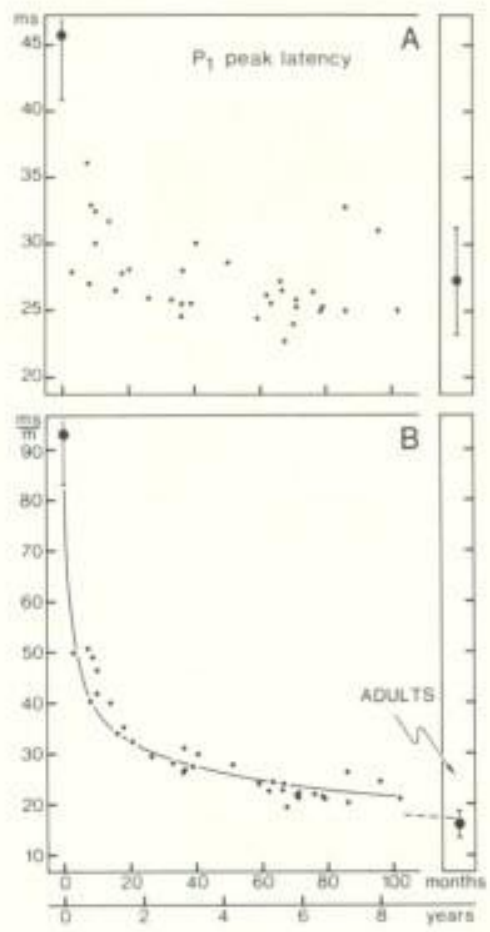

Fig. 11. Pooled data on $P_{1}$ peak latency, presented as in Fig. 9. Abscissae, age in months or years (bottom scale). $A$, latency to the first peak of the early positive component in msec, $B$, same points divided by the body length in $\mathrm{msec} / \mathrm{m}$, with a curve drawn according to the calculated power function: $y=$ $68.13 \mathrm{x}^{-0.250}\left(\mathrm{~N}=36 ; \mathrm{r}^{2}=0.909\right)$.

The difference between the children in their first 2 years $(\mathrm{N}=8)$ and the adults $(\mathrm{N}=16)$ was significant for $P_{1}$, but not for $N_{1}$ (Table I). The ratio of the sizes of $N_{1}: P_{1}$ disclosed a very consistent difference between the means of 0.93 in the young children and 0.31 in the adults (Table I).

Nomenclature of SEP early components. Among the several nomenclatures proposed, the one associating $\mathrm{N}$ or $\mathrm{P}$ (for surfacenegative or positive) and the mean peak latency (Vaughan 1969) appears quite helpful. Thus in normal adults one would describe $\mathrm{N}_{22}$ (Fig. 10,A), $\mathrm{P}_{27}$ (Fig. 11, A) and $\mathrm{P}_{45}$ (Fig. 8, E) components. However, in the newborn one would have to speak of $\mathrm{N}_{31}$ and $\mathrm{P}_{46}$ for components which can 
no longer be considered different in nature after the evidence in this paper that the changes are progressive from the one to the other during maturation. We do not think that the above nomenclature makes sense when dealing with a component such as the early negativity, which discloses such large and consistent changes in latency during growth. Although $\mathrm{N}_{22}$ is appropriate for studies on normal adults and with finger stimulation $\left(\mathrm{N}_{20}\right.$ for nerve stimulation at the wrist), $\mathrm{N}_{1}$ seems preferable in maturation studies.

\section{Discussion}

This paper presents the first quantitative study of the normal maturation of SEP early components in man from birth to adulthood. Besides disclosing several SEP developmental changes which progress surprisingly slowly and extend over a span of at least 7 years after birth, the results provide reference data and growth profiles which should allow comparison with human populations other than the Western European Caucasian subjects considered here. They should also be helpful in the proper evaluation of SEP findings in infants and children with various genetic or acquired disorders of the nervous system.

It is well known that the recording of bioelectrical potentials in awake children can be very difficult when prolonged runs are to be obtained in an appropriate state of muscle relaxation, without movement artifacts and eye blinks. A deliberate effort of child entertainment and persuasion with rewards and the use of on-line or off-line electronic designs for rejecting from the SEP average the EEG samples with artifacts or amplifier overload (see Methods) made it possible to complete the program in each of the 35 children. If the above problems can be taken care of, we think it more satisfactory to study SEPs in awake subjects, thereby avoiding the uncertain- ties associated with different and sometimes poorly defined depths of (generally drug-induced) sleep and also with the diverse changes of SEP wave forms with sleep stages in subjects of widely different ages. It would further be a nuisance to have to put to sleep the adult volunteers and the very cooperative older children for the only reason that their SEP data should be comparable with those of the younger subjects who would have been studied in sleep. The known difficulty of maintaining newborns awake for any period of time does not really complicate the problem, since the newborn SEPs are very similar in the waking state and in REM sleep (Desmedt and Manil 1970 ), as is also the case for normal adults (Goff et al. 1966). Therefore the newborn SEPs considered here were all recorded in standard REM sleep and compared with SEPs in awake children and adults.

The paper focuses on the early SEP components because they have more reproducible features in different subjects of similar age than the late components, the latter being markedly influenced by cognition, expectancy, habituation and other correlates (Vaughan 1969; Donchin and Lindsley 1969). Reproducibility under reasonably straightforward recording conditions is obviously a requirement for use of the standardized data in subsequent clinical applications. In addition the feasibility of accurate estimation, from the early SEP component $\mathrm{N}_{1}$, of the earliest time of arrival of the afferent sensory signals at the parietal cortex (Fig. 5, 6, 7) is a major asset for the quantitative analysis of peripheral sensory nerve, lemniscal and thalamo-cortical conduction times (Desmedt 1971; Desmedt et al. 1973). For these reasons, a major effort has been made to obtain in each subject 3-6 separate runs of average SEPs with a consistently high signal-tonoise ratio, thereby permitting estimations of latencies and durations of components with a precision of $0.2 \mathrm{msec}$. This is of course only possible if the amplifier-re- 
corder-averager system presents an adequate bandpass extending to 1 , and better, to $3 \mathrm{kc}$ (Desmedt et al. 1974). Two other points which are essential for standardization of SEP data are: (a) the electrical stimulation of fingers (Dawson 1956; Desmedt 1971), not mixed nerves, with currents of stable and known intensity, and (b) the maintenance of a normal temperature in the stimulated limb thereby avoiding spurious overestimations of SEP latencies arising from slowed peripheral conduction in cool limbs (Desmedt 1973).

The problem of choosing truly comparable stimulus intensities in the different subjects compared was studied in the newborns. The latency and duration of the early $\mathrm{N}_{1}$ component were found to increase, sometimes considerably, for near-threshold stimuli (Fig. 2, 3). The $\mathrm{N}_{1}$ focus was more restricted in young subjects (Fig. 6, G) than in adults, possibly because of differences in cortical generators and in thickness of bone and surrounding tissues, and even more so at low stimulus intensities (Fig. 1). Therefore finger stimuli of 5 or more times threshold were used in order to obtain fairly standard early components which would not be significantly affected and biased by the unavoidable range of sizes of the afferent volleys in the different subjects to be compared.

There is extensive evidence for a predominantly surface-negative SEP in the cortex of immature mammals, such as the kitten (Oeconomos and Scherrer 1953; Scherrer and Oeconomos 1954; Marty 1962; Purpura et al. 1964), the premature sheep at 75-90 days gestational age (Bernhard et al. 1967; Molliver 1967; Persson 1973), the rabbit (Marty 1962; Verley and Rokyta 1972) and the premature baboon (Desmedt 1971). This SEP pattern has generally been related to the precocious development of the superficial axo-dendritic synapses (Purpura 1961; Marty 1962; Voeller et al. 1963; Purpura et al. 1964; Aström 1967; Meller et al. 1968; Molliver and Van der Loos
1970; Adinolfi 1971). With later development, at birth or even slightly thereafter in immature-born species such as the cat, the early surface negativity of SEP decreases and disappears, while the early activation by afferent axons becomes predominant in the deeper layers of the cortex, along with the development of basal dendrites of the deep seated cortical pyramidal cells. This is not the place to elaborate detailed animal observations, except to emphasize that in man, the prominent early surfacenegative component $\mathrm{N}_{1}$ found at birth (Desmedt et al. 1967; Desmedt and Manil 1970) changes at an exceptionally slow rate over the following years (Fig. 8, 10) and that it persists with a decreased duration in the adult man while the subsequent positivity increases in voltage (Table I). Such changes in relative prominence of the early negative and positive components is in line with the anatomical evidence just quoted. However, the persistence of a sizeable early negativity in adulthood is a special feature characteristic of man which raises important questions (Desmedt 1971).

The quantitative changes in duration of the $N_{1}$ component are progressive and by the age of 8 years the $N_{1}$ duration is just reaching the adult range (Fig. $9, A$ ). It must be said that we have been considering the total $\mathrm{N}_{1}$ duration, including the small $\mathrm{N}_{1}$ "step" which precedes the main deflection by about $1.5 \mathrm{msec}$ in a number of children (Fig. 7, D-F). These steps are thought to result from the earlier arrival at the parietal cortex of a small group of action potentials conducted faster by a few actively maturing somatosensory axons. There seems to be no reason for not including in $\mathrm{N}_{1}$ such subcomponents of similar polarity and of slightly shorter latency (see above).

The latencies to onset and to peak of $\mathrm{N}_{1}$ disclose changes (Fig. 9, $B ; 10, A$ ) which are not easily understood until one takes into account the body growth of the child. Dividing latencies by body length gives dimensions of reciprocal velocity (msec:m) (Fig. 
$9, C)$. The body length provides of course only a rough estimation of the changes in the actual length of the pathway travelled by the afferent impulses, but it can be said that the subjects studied had rather normal body and limb proportions. This function lumps together the peripheral and central conduction times and the synaptic delays at the dorsal column nuclei and at the thalamic ventro-basal nucleus, which is admittedly a rather rough procedure. It appears all the more interesting that the scatter of points is in fact reduced in such a plot (compare Fig. 9, $B$ to $C$, and Fig. 10, $A$ to $B)$ and that a negative power function can be calculated with a highly consistent correlation coefficient $r^{2}$. Such graphs can be looked at as showing the variation of SEP "latencies" for a population which would not grow and which would have a standard body size of one meter. Thus the latency to onset of $N_{1}$ would be $46 \mathrm{msec}$ in the "standard" newborn and $11 \mathrm{msec}$ in the "standard" adult, both of $1 \mathrm{~m}$ body size. The body growth after birth and the spurt of increase in length of the somatosensory pathway at puberty are both, so to speak, removed from such a plot, which thus helps to visualize a hitherto unsuspected extent of the somatosensory maturation and which emphasizes its slowness, since adult values are not approached by the child SEP until the age of about 8 years (Fig. 9, 10).

While the data on $\mathrm{N}_{1}$ duration and on the changes in pattern of the subsequent early positivity provide some clues to the developmental changes in intrinsic cortical processes, those on the onset latencies no doubt reflect predominantly the changes in conduction times from finger to cortex. A subsequent paper will discuss the relative maturation rates of conduction along the peripheral and central parts of the somatosensory pathway (cf. Desmedt 1971; Desmedt et al. 1973).

\section{Summary}

The early components of the somatosensory evoked potential (SEP) were analysed in 39 normal newborns in REM sleep, 35 normal awake children between 1 month and 9 years and 16 normal awake adults. Electrical pulses were delivered at random intervals to fingers of the contralateral hand. The SEP were averaged from several electrodes in the parietal scalp focus and several runs were compared to estimate precise latencies and durations (Fig. 5, 6, 7). The system bandpass extended to $3 \mathrm{kc}$ and many precautions were taken to exclude interference. The limb temperature was carefully maintained at normal value in order to avoid undue slowing of peripheral conduction velocity.

The SEP presented markedly increased latencies for near-threshold stimuli (Fig. 3) while becoming even more focalised (Fig. 1). Background data were obtained in order to standardize the parameters for the maturation study (Fig. 2, 3, 4). In the children, the early negative component was found to undergo progressive changes. It was only at the age of about 8 years that the adult pattern was approached (Fig. 8, 9, 10, 11). The duration of the early negative $\mathrm{N}_{1}$ component decreased quite progressively. The latencies to onset and to peak were also shown to follow a highly consistent pattern when the body length of the subjects was taken into account (Fig. 9, 10). By dividing the data by the body length, functions were obtained which could be said to apply to a "standard" individual whose body length did not change from birth to adulthood and remained at one meter. Such plots made it possible to appreciate the true extent of the SEP maturational changes from birth.

The quantitative data thus provided should serve as a useful reference for subsequent studies on developmental changes of the brain and for clinical applications to diseased children. 


\section{Résumé}

Maturation des potentiels évoqués somesthésiques chez l'enfant normal et notamment de la composante initiale $N_{1}$

Les composantes précoces du potentiel évoqué somesthésique ont été analysées chez 39 nouveaux-nés normaux au cours de phases de sommeil à mouvements rapides des yeux, chez 35 enfants normaux éveillés de 1 mois à 9 ans et chez 16 adultes normaux éveillés. Des stimuli électriques ont été délivrés à intervalles aléatoires à un ou plusieurs doigts de la main contralatérale. Les potentiels évoqués ont été moyennés à partir de plusieurs électrodes placées sur le cuir chevelu, au niveau du foyer de la projection pariétale. Chez chaque sujet on a comparé plusieurs essais afin de pouvoir déterminer avec précision les latences et les durées des composantes. La bande passante du système s'étendait jusqu'à $3 \mathrm{kc}$ pour éviter la distortion des composantes précoces rapides. On a pris beaucoup de précautions pour éviter les interférences et pour obtenir un rapport signal-bruit très satisfaisant (Fig. 5, 6, 7). La température du membre supérieur a été vérifiée soigneusement et maintenue à la normale afin d'exclure un ralentissement périphérique de la vitesse de conduction des influx afférents.

Le potentiel évoqué somesthésique présente une importante augmentation de sa latence pour les stimuli voisins du seuil (Fig. 3) et il se focalise alors plus étroitement sur la région pariétale (Fig. 1). Des données systématiques ont été obtenues afin de standardiser les paramètres en vue de l'étude des processus de maturation (Fig. 2, 3, 4). La composante précoce surface-négative $\mathrm{N}_{1}$ subit des modifications très progressives chez les enfants en fonction de l' âge, et ce n' est qu' à l' âge de 8 ans qu' elle s' approche du type adulte (Fig. 8, 9, 10,11). La durée de $\mathrm{N}_{1}$ diminue très progressivement. Les latences de début et de pic présentent éga- lement un profil extrêmement cohérent lorsqu'on tient compte des variations de taille des sujets (Fig. 9, 10). En divisant les chiffres de latence par la taille corporelle, on obtient des relations qui peuvent être considérées comme s'appliquant à des individus "standards" dont la taille ne changerait pas de la naissance à l' état adulte et resterait égale à un mètre. Ces relations permettent de mieux apprécier l'étendue importante des modifications du potentiel évoqué au cours de la maturation post-natale.

Les données quantitatives présentées apportent un cadre de référence utile pour les études ultérieures sur le développement cérébral chez l'homme et pour les applications cliniques.

This work has been supported by grants from the Fonds National de la Recherche Scientifique, by the Fonds de la Recherche Scientifique Médicale and by the National Institute of Neurological Diseases and Stroke, National Institutes of Health of the United States.

\section{References}

Adinolfi, A.M. The postnatal development of synaptic contacts in the cerebral cortex. In M.B. Sterman, D.J. McGinty and A.M. Adinolfi (Eds.), Brain development and behavior. Academic Press, New York, 1971: 71-87.

Allison, T. Recovery functions of somatosensory evoked responses in man. Electroenceph. clin. Neurophysiol., 1962, 14: 331-343.

Anders, Th., Emde, R. and Parmelee, A. A manual of standardized terminology, techniques and criteria for scoring of states of sleep and wakefulness in newborn infants. UCLA Brain Information Service, Los Angeles, Calif., 1971.

Apgar, V. A proposal for a new method of evalua. tion of the newborn infant. Curr. Res. Anesth., $1953,32: 260-267$.

Aström, K.E. On the early development of the isocortex in fetal sheep. In C.G. Bernhard and J.P. Schadé (Eds.), Progress in brain research, vol. 26, Developmental neurology. Elsevier, Amsterdam, 1967: 1-59.

Bernhard, C.G., Kolmodin, G.M. and Meyerson, B.A. On the prenatal development of function and structure in the somesthetic cortex of the sheep. In C.G. Bernhard and J.P. Schadé (Eds.), 
Progress in brain research, vol. 26, Developmental neurology. Elsevier, Amsterdam, 1967: 60-77.

Carmeliet, J., Debecker, J. and Desmedt, J.E. A random interval generator using beta ray emission. Electroenceph. clin. Neurophysiol., 1971, $30: 354-356$.

Cracco, R.Q. The initial positive potential of the human scalp-recorded somatosensory evoked response. Electroenceph. clin. Neurophysiol., 1972, $32: 623-629$.

Dawson, G.D. The relative excitability and conduction velocity of sensory and motor nerve fibres in man. J. Physiol. (Lond.), 1956, 131: 436-451.

Debecker, J. and Carmeliet, J. Automatic suppression of eye movement and muscle artifacts when averaging tape recorded cerebral evoked potentials. Electroenceph. clin. Neurophysiol., 1974, $37: 513-515$.

Debecker, J. et Desmedt, J.E. Les potentiels évoqués cérébraux et les potentiels de nerf sensible chez l'Homme. Utilisation de l'ordinateur numérique Mnemotron. Acta neurol. belg., 1964, 64: 12121248.

Desmedt, J.E. Somatosensory cerebral evoked potentials in man. In A. Rémond (Ed.), Handbook of EEG and clinical neurophysiology, vol. 9. Elsevier, Amsterdam, 1971: 55-82.

Desmedt, J.E. The neuromuscular disorder in myasthenia gravis. 1. Electrical and mechanical responses to nerve stimulation in hand muscles. In J.E. Desmedt (Ed.), New developments in electromyography and clinical neurophysiology, Vol. 1. Karger, Basel, 1973:241-304.

Desmedt, J.E., Brunko, E., Debecker, J. and Carmeliet, J. The system bandpass required to avoid distortion of early components when averaging somatosensory evoked potentials. Electroenceph. clin. Neurophysiol., 1974, 37: 407-410.

Desmedt, J.E. and Debecker, J. The somatosensory cerebral evoked potentials of the sleeping human newborn. In C.D. Clemente, D.P. Purpura and F.E. Mayer (Eds.), Sleep and the maturing nervous system. Academic Press, New York, 1972: $229-239$.

Desmedt, J.E. and Manil, J. Somatosensory evoked potentials of the normal human neonate in REM sleep, in slow wave sleep and in waking. Electroenceph. clin. Neurophysiol., 1970, 29: 113126.

Desmedt, J.E., Manil, J., Chorazyna, H. et Debecker, J. Potentiel évoqué cérébral et conduction corticipète pour une volée $\mathrm{d}^{\prime}$ influx somesthésiques chez le nouveau-né normal. C.R. Soc. Biol. (Paris), 1967, 161: 205-208.

Desmedt, J.E., Noël, P., Debecker, J. and Namèche, J. Maturation of afferent conduction velocity as studied by sensory nerve potentials and by cerebral evoked potentials. In J.E. Desmedt (Ed.), New developments in electromyography and clinical neurophysiology, Vol. 2. Karger, Basel, 1973: 52-63.

Donchin, E. and Lindsley, D.B. (Eds.), Average evoked potentials. NASA SP-191, Washington, D.C., 1969,400 p.

Giblin, D.R. Somatosensory evoked potentials in healthy subjects and in patients with lesions of the nervous system. Ann. N.Y. Acad. Sci, 1964, 112: 93-142.

Goff, W.R., Allison, T., Shapiro, A. and Rosner, B.S. Cerebral somatosensory responses evoked during sleep in man. Electroenceph. clin. Neurophysiol., 1966, 21: 1-9.

Goff, W.R., Matsumiya, Y., Allison, T. and Goff, G.D. Cross-modality comparisons of averaged evoked potentials. In E. Donchin and D.B. Lindsley (Eds.), Average evoked potentials. NASA SP-191, Washington, D.C., 1969: 95-141.

Halliday, A.M. Changes in the form of cerebral evoked responses in man associated with various lesions of the nervous system. Electroenceph. clin. Neurophysiol., 1967, Suppl. 25: 178192.

Hougardy, J. and Desmedt, J.E. Sound-proofed rooms for experimentation in sensory physiology. Arch, int. Physiol., 1967, 75: 352-353.

Hrbek, A., Karlberg, P. and Olsson, T. Development of visual and somatosensory evoked responses in pre-term newborn infants. Electroenceph. clin. Neurophysiol, 1973, 34: 225232.

Laget, P., Raimbault, J, et Thieriot-Prevost, G. L'évolution des potentiels évoqués somesthésiques chez le nourrisson normal durant les deux premiers mois de la vie. C.R. Soc. Biol. (Paris), 1973a, 163: 649-654.

Laget, P., Raimbault, J. et Thieriot-Prevost, G. L'êvolution du potentiel évoqué somesthésique (P.E.S.) chez l'enfant normal âgé de 61 jours à 7 ans. C.R. Soc. Biol. (Paris), 1973b, 167: $831-835$.

Marty, R. Développement post-natal des réponses sensorielles du cortex cérébral chez le chat et le lapin. Arch. Anat. micr. Morph. exp., 1962, 51: $129-264$.

Meller, K., Breipohl, W. and Glees, P. Synaptic organization of the molecular and the outer granular layer in the motor cortex in the white mouse during postnatal development. A Golgi and electron-microscopical study. Z. Zellforsch., $1968,92: 217-231$.

Molliver, M.E. An ontogenetic study of evoked somesthetic cortical responses in sleep. In C.G. Bernhard and J.P. Schadé (Eds.), Progress in brain research, Vol. 26, developmental neu- 
rology. Elsevier, Amsterdam, 1967; 78-91.

Molliver, M.E. and Van der Loos, H. The ontogenesis of cortical circuitry: the spatial distribution of synapses in somesthetic cortex of newborn dog. Ergebn. Anat. Entwickl.-Gesch., 1970, 42: $1-53$.

Noèl, P. and Desmedt, J.E. Somatosensory cerebral evoked potentials after vascular lesions of the brain-stem and diencephalon. Brain, 1975, 98: 113-128.

Oeconomos, D. et Scherrer, J, Etude des potentiels évoqués corticaux somesthésiques chez le chat nouveau-né. C.R. Soc. Biol. (Paris), 1953, 147: 1229-1232.

Persson, H.E. Development of somatosensory cortical functions. Acta Physiol. scand., 1973, Suppl. $394: 64$.

Purpura, D.P. Morphophysiological basis of elementary evoked response patterns in the neocortex of the newborn cat. Ann. N.Y. Acad. Sci., 1961, $92: 840-859$.

Purpura, D.P., Shofer, R.J., Housepian, E.M. and Noback, C.R. Comparative ontogenesis of structure-function relations in cerebral and cerebellar cortex. Progress in brain research, Vol. 4. Elsevier, Amsterdam, $1964: 187-221$.

Roffwarg, H.P., Muzio, J.N. and Dement, W.C. Ontogenic development of the human sleepdream cycle. The prime role of "dreaming sleep" in early life may be in the development of the central nervous system. Science, 1966, 152 : $604-619$.

Scherrer, J. et Oeconomos, D. Réponses corticales somesthésiques du mammifère nouveau-né comparées à celles de l'animal adulte. Etud, néonatal., 1954, 3: 199-216.

Schimmel, $H$. The $( \pm)$ reference: accuracy of estimated mean components in average response studies. Science, 1967, 157: 92-93.

Small, D.G., Beauchamp, M. and Matthews, W.B. Subcortical somatosensory evoked responses in man. In J.E. Desmedt (Ed.), New developments in auditory and somatosensory evoked potentials in the human brain. Oxford University Press, 1975 (in press).

Vaughan, H.G. The relationship of brain activity to scalp recordings of event-related potentials. In E. Donchin and D.B. Lindsley (Eds.), Average evoked potentials. NASA SP-191, Washington, D.C., 1969: 45-94.

Verley, R. et Rokyta, R. Ontogenèse du potentiel évoqué cortical somesthésique chez le lapin nouveau-né. Arch. sci. physiol., 1972, 26: 267276.

Voeller, K., Pappas, G.D. and Purpura, D.P. Electron microscope study of development of cat superficial neocortex. Exp. Neurol., 1963, 7: 107130 . 